\title{
Petrography and Mineral Chemistry of Monte Epomeo Green Tuff, Ischia Island, South Italy: Constraints for Identification of the Y-7 Tephrostratigraphic Marker in Distal Sequences of the Central Mediterranean
}

\author{
Massimo D'Antonio ${ }^{1, *}$, Ilenia Arienzo ${ }^{2}$, Richard J. Brown ${ }^{3}$, Paola Petrosino ${ }^{1}$, Carlo Pelullo ${ }^{1}$ \\ and Biagio Giaccio ${ }^{4}$
}

1 Dipartimento di Scienze della Terra, dell'Ambiente e delle Risorse, Università degli Studi di Napoli Federico II, Complesso Universitario di Monte Sant'Angelo, Via Vicinale Cupa Cintia 21, 80126 Napoli, Italy; paola.petrosino@unina.it (P.P.); carlo.pelullo@unina.it (C.P.)

2 National Institute of Geophysics and Volcanology, Osservatorio Vesuviano, Via Diocleziano 328, 80124 Naples, Italy; ilenia.arienzo@ingv.it

3 Department of Earth Sciences, Durham University, Durham DH1 3LE, UK; richard.brown3@durham.ac.uk

4 Istituto di Geologia Ambientale e Geoingegneria, IGAG-CNR, Via Salaria km 29.300, 00015 Rome, Italy; biagio.giaccio@cnr.it

* Correspondence: masdanto@unina.it

Citation: D'Antonio, M.; Arienzo, I.; Brown, R.J.; Petrosino, P.; Pelullo, C.; Giaccio, B. Petrography and Mineral Chemistry of Monte Epomeo Green Tuff, Ischia Island, South Italy: Constraints for Identification of the Y-7 Tephrostratigraphic Marker in Distal Sequences of the Central Mediterranean. Minerals 2021, 11, 955. https://doi.org/10.3390/ $\min 11090955$

Academic Editor: Alexey V. Ivanov

Received: 6 August 2021

Accepted: 29 August 2021

Published: 31 August 2021

Publisher's Note: MDPI stays neutral with regard to jurisdictional claims in published maps and institutional affiliations.

Copyright: (C) 2021 by the authors Licensee MDPI, Basel, Switzerland. This article is an open access article distributed under the terms and conditions of the Creative Commons Attribution (CC BY) license (https:// creativecommons.org/licenses/by/ $4.0 /)$.

\begin{abstract}
The 56 ka Monte Epomeo Green Tuff (MEGT) resulted from the largest volume explosive eruption from Ischia island (south Italy). Its tephra is one of the main stratigraphic markers of the central Mediterranean area. Despite its importance, a detailed characterisation of the petrography and mineral chemistry of MEGT is lacking. To fill this gap, we present detailed petrographic description and electron microprobe mineral chemistry data on samples collected on-land from the MEGT. Juvenile clasts include pumice, scoria, and obsidian fragments with porphyritic/glomeroporphyritic, vitrophyric, and fragmental textures. The porphyritic index is $13-40 \mathrm{vol} \%$, and phenocryst phases include alkali-feldspar, plagioclase, clinopyroxene, ferrian phlogopite, and titano-magnetite, in order of decreasing abundance; accessory phases include sphene, hydroxy-fluor-apatite, and rare edenite. Plagioclase varies from predominant andesine to subordinate oligoclase, whereas alkali-feldspar is more variable from sanidine to anorthoclase; quasi-pure sanidine commonly occurs as either rim or recrystallisation overgrowth of large phenocrysts due to hydrothermal alteration. Secondary minerals include veins and patches of carbonate minerals, Fe-Mn oxyhydroxides, clay minerals, and zeolites. Clinopyroxene is ferroan diopside $\left(\mathrm{En}_{45-29} \mathrm{Fs}_{7-27}\right)$ and never reaches Na-rich compositions. This feature allows the discrimination of MEGT from aegirine-bearing, distal tephra layers erroneously attributed to MEGT, with implications for the areal distribution of Ischia explosive deposits.
\end{abstract}

Keywords: Monte Epomeo Green Tuff; Ischia island; petrography; mineral chemistry; clinopyroxene; tephrostratigraphy; tephrochronology; Mediterranean

\section{Introduction}

The Monte Epomeo Green Tuff (MEGT) is the most important volcanic unit of Ischia island (Gulf of Naples, south Italy; Figure 1A). It is the product of a complex, paroxysmal explosive eruption that occurred $\approx 56 \mathrm{ka}[1,2]$ on the island and that resulted in caldera collapse and the wide dispersal of ash across the central Mediterranean. The MEGT is a key stratigraphic tephra marker, referred to as $\mathrm{Y}-7$, and it is found in several distal continental and deep sea sedimentary records of the central Mediterranean area (Figure 1B; e.g., [2-9]), including Palaeolithic sites [10]. The total volume of erupted magma has been estimated to $\approx 9-15 \mathrm{~km}^{3}$ based on caldera dimensions [11] and $\approx 40 \mathrm{~km}^{3}$ based on areal distribution of proximal and distal fallout deposits [9]. The distal deposits of the MEGT 
are dispersed to S-SE and occur up to $540 \mathrm{~km}$ away in the Ionian Sea (Figure 1B; [9]). Therefore, the MEGT represents one of the largest quaternary explosive eruptions in the central Mediterranean area.

The typical green colour of the MEGT deposits allows their quick recognition in the field. This results from the alteration of the tuff in a shallow marine environment ([12] and references therein), following the emplacement of large volumes of ignimbrite within the caldera during the eruption. Despite the volcanological and tephrochronological importance of MEGT, as well as its widespread use as building stone in the Neapolitan area since prehistory [13], a systematic characterisation of the petrography and mineral chemistry of its products has not yet been attempted: Poli et al. (1987) [14] included a few analyses of MEGT minerals in their large Ischia-wide database. Here, we present detailed petrographic description and electron microprobe analysis of crystalline and glassy phases of rock samples representative of the MEGT main lithological units as re-defined by Brown et al. (2008) [15]. The results, together with those of a preliminary study on just one sample [12], allow a thorough mineral-chemical characterisation of the MEGT products and an assessment of chemical variation of their primary minerals, as well as of the main secondary minerals. This characterisation provides a useful tool for recognising the deposits of MEGT in distal tephra successions and can be integrated with geochemical (major oxides and trace elements contents) and isotopic ( $\mathrm{Sr}$ and Nd isotope ratios) tracers, which are proven to be effective in many instances (e.g., [8,16-18]).

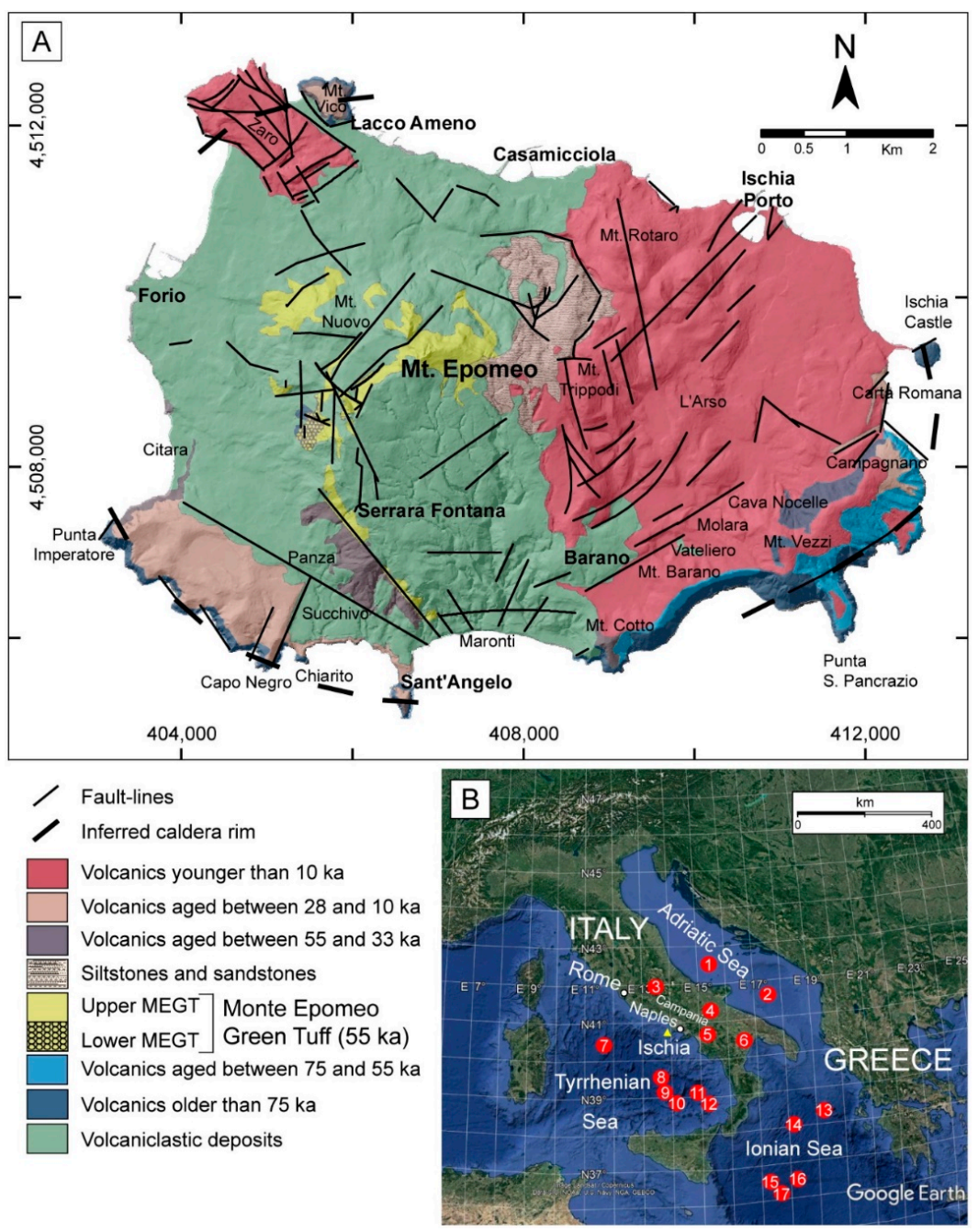

Figure 1. (A) Geological sketch map of Ischia island, showing the areal distribution of the main volcanic units, including the Monte Epomeo Green Tuff (modified after D'Antonio et al., 2013 [19]). (B) Map of 
the central Mediterranean area; numbered red circles indicate the main distal locations where the MEGT products have been either recognised or hypothesised: 1-PRAD 1-2 bore hole, Adriatic Sea [20]; 2-KET 8218 bore hole, Adriatic Sea [3]; 3-Fucino Basin, Abruzzo, Central Italy [2]; 4-Lago Grande di Monticchio, Basilicata [4,6]; 5-San Gregorio Magno basin, Campania [7,8]; 6-Oscurusciuto [10]; 7, 8, 10, 11-KET 8022, KET 8004, KET 8003, KET 8011 bore holes, Tyrrhenian Sea [3]; 9-ODP Leg 107, Site 650, Tyrrhenian Sea [21]; 12—Stromboli, Aeolian Archipelago [22]; 13, 14, 16-RC9-190, RC9-191, V10-68 bore holes, Ionian Sea [23]; 15-M25/4-11 bore hole, Ionian Sea ([9] and references therein); 17-ODP Leg 160 Site 964 and KC01B bore holes, Ionian Sea [5,24].

\section{Geological, Volcanological, and Petrological Background}

Ischia island is an active volcanic field composed predominantly of volcanic rocks and subordinate terrigenous sedimentary deposits. Its morphology is dominated by Mount Epomeo, $787 \mathrm{~m}$ a.s.l., in the centre of the island, that is the result of long-lasting block resurgence [25]. The volcanic rocks include pyroclastic deposits produced by fallout and pyroclastic density currents, and lava flows and domes. The present-day island is the result of a complex interplay between tectonic and volcanic activity accompanied by erosion, slope instability, and sedimentation [25-28].

Volcanic activity on Ischia initiated prior to $150 \mathrm{ka}$, the age of the oldest dated volcanic deposit on the island, which is not the stratigraphically lowermost one [1,26]. The most recent eruption, that emplaced the Arso lava flow, occurred in 1302 AD. Low-energy seismicity, fumaroles, and hot springs testify to the active state of the volcanic complex (e.g., [12,29-31] and references therein). Volcanic activity on Ischia has been subdivided in five cycles: between >150 and $75 \mathrm{ka}$; between 75 and $55 \mathrm{ka}$; between 55 and $33 \mathrm{ka}$; between 28 and $12 \mathrm{ka}$; and between $10 \mathrm{ka}$ and $1302 \mathrm{AD}[14,15,25,26,32-37]$. The MEGT represents the most voluminous deposit of the third cycle of volcanic activity of Ischia $[14,26,33]$. It has been dated by several authors (e.g., $[1,38])$. The most recent, ${ }^{40} \mathrm{Ar} /{ }^{39} \mathrm{Ar}$ age of $56.1 \pm 1.0$ $(2 \sigma) \mathrm{ka}$, was obtained on the TF-7 tephra collected from the Fucino Quaternary lacustrine sequence, central Italy, and has been confidently attributed to the MEGT eruption [2]. The volcanic products of Ischia belong to a mildly alkaline (potassic) magma evolution series that includes rare shoshonites through latites, subordinate phonolites, and dominant trachytes. The evolved rocks are volumetrically predominant over the poorly evolved ones. Interestingly, the evolved rocks become progressively less potassic and more sodic with respect to more primitive shoshonites and latites. This is due to strong fractionation of alkali-feldspar and to the development of a peralkaline character (e.g., [11,14,15,33,39-43]).

The products of MEGT crop out extensively on Ischia, especially in its central-western sector, whereas they are covered by more recent volcanic products in the eastern sector (Figure 1A). The rim of the MEGT caldera is marked by cliffs containing pre-MEGT products on the SW, NW, NE, and SE coasts [44] (Figure 1A) and has been inferred from geophysical modelling ([45] and references therein). Both intra- and extracaldera deposits of MEGT were identified and studied [15]. Based on the occurrence inside the caldera of two thick ignimbrites separated by a meter of volcaniclastic sediments, the intracaldera deposits were subdivided into two units named Lower MEGT and Upper MEGT. The extracaldera deposits include a coarse-grained Plinian pumice fall deposit, a widespread lithic breccia, and a distal ignimbrite that crops out in southwest Campi Flegrei. The lithology of MEGT juvenile clasts varies from vesicular pumice to dense juvenile material and obsidian [15]. They are potassic trachyte and phonolite in composition [11].

\section{Materials and Methods}

For the purposes of this work, several samples of Monte Epomeo Green Tuff intra- and extracaldera units outcropping extensively on Ischia island were selected. Polished thin sections were prepared to observe the main petrographic features of the samples under a binocular polarised light microscope. Pumice samples have been discarded for mineral chemistry determinations, because they resulted profoundly altered upon petrographic observation, with almost no relic minerals or glass. Conversely, scoria and obsidian samples 
are either almost fresh or only partially altered. On a selected set of thin sections, electron microprobe analysis (EMPA) has been performed at the HP-HT Laboratory of Experimental Volcanology and Geophysics of Istituto Nazionale di Geofisica e Vulcanologia in Rome, Italy. The EMPA measurements were carried out using a Jeol JXA 8200 Superprobe (JEOL, Tokyo, Japan), equipped with five wave-length dispersive (WDS) X-ray spectrometers, employing PET, TAP, and LiF as diffraction crystals, and an energy-dispersive (EDS) $\mathrm{X}$ ray spectrometer. The operating conditions were $15 \mathrm{kV}$ accelerating voltage and $7 \mathrm{nA}$ probe current. A probe diameter of $5 \mu \mathrm{m}$, with a final spot size of about $7 \mu \mathrm{m}$, was used to minimise alkali loss. Counting times were $10 \mathrm{~s}$ on the peak and $5 \mathrm{~s}$ on each of two background positions; inter-elemental effects were corrected through a ZAF (Z: atomic number; A: absorption; F: fluorescence) method. Calibration was achieved by means of the following standards from Micro-Analysis Consultants (MAC; [46]): albite (Si on PET, Al on TAP, Na on TAP), forsterite (Mg on TAP), augite (Fe on LIF), apatite (Ca on PET), orthoclase (K on PET), rutile (Ti on PET), and rhodonite (Mn on LIF). Smithsonian augite [47] and MAC augite were used as quality monitor standards and for calculating accuracy and precision. Accuracy was better than $1-5 \%$ for abundances higher than $1 \mathrm{wt} \%$ and better than $5-10 \%$ for elements with abundances lower than $1 \mathrm{wt} \%$. Precision was generally better than $1-5 \%$ for all analysed elements.

All analyses presented in this work are original data, except for those of sample MEGT0322, which were already published [12]. Representative EMP analyses are listed in Supplementary Table S1.

\section{Results}

The main petrographic features of the investigated MEGT samples are listed in Table 1 and in the caption of Figure 2, describing representative thin section photomicrographs. Additional thin section photomicrographs are provided in Supplementary Figure S1. Textures are variable and include porphyritic/glomeroporphyritic, seriate, vitrophyric, and fragmental varieties. Both primary and secondary (i.e., alteration) minerals occur in the MEGT products. The main primary phenocryst paragenesis includes predominant alkali-feldspar, subordinate plagioclase, clinopyroxene and black mica (phlogopite), and accessory opaque oxide (titano-magnetite), sphene, apatite, and rare amphibole. The porphyritic index varies from 13 to 40 vol.\%. Secondary minerals are mostly carbonate and Fe-Mn oxyhydroxides, subordinate clays, and zeolites (analcite). The compositional features of the crystalline and glassy phases as determined through EMPA are described in detail as follows.

Table 1. Main petrographic features of the investigated MEGT samples.

\begin{tabular}{cccc}
\hline Sample & Unit & Lithotype & Texture \\
\hline OIS0325 $^{1}$ & Extracaldera upper & Scoria & Vitrophyric \\
OIS0321 $^{1}$ & Extracaldera lower & Pumice & Vitrophyric \\
MEGT0322 & Intracaldera intermediate & Ignimbrite matrix-rich & Fragmental \\
MEGT0320 & Intracaldera intermediate & Crystals-rich pumice & Porphyritic \\
MEGT0319 & Intracaldera intermediate & Mafic scoria & Porphyritic \\
MEGT0318 & Obsidian & Vitrophyric & Porphyritic, \\
OIS0102 ${ }^{1}$ & Intracaldera intermediate & Scoria & glomeroporphyritic, seriate \\
MEGT0304 & Intracaldera & Fragmental \\
MEGT0303 & Intracaldera lower & Vesicular clast (tuff) & Fragmental \\
MEGT0302b & Intracaldera lower & Scoriaceous bomb & Porphyritic, \\
MEGT0302 & & & glomeroporphyritic, seriate \\
MEGT0301 & Intracaldera lower & Porphyritic, & glomeroporphyritic \\
porphyritic
\end{tabular}

${ }^{1}$ sample analysed with EMPA (Supplementary Table S1). 


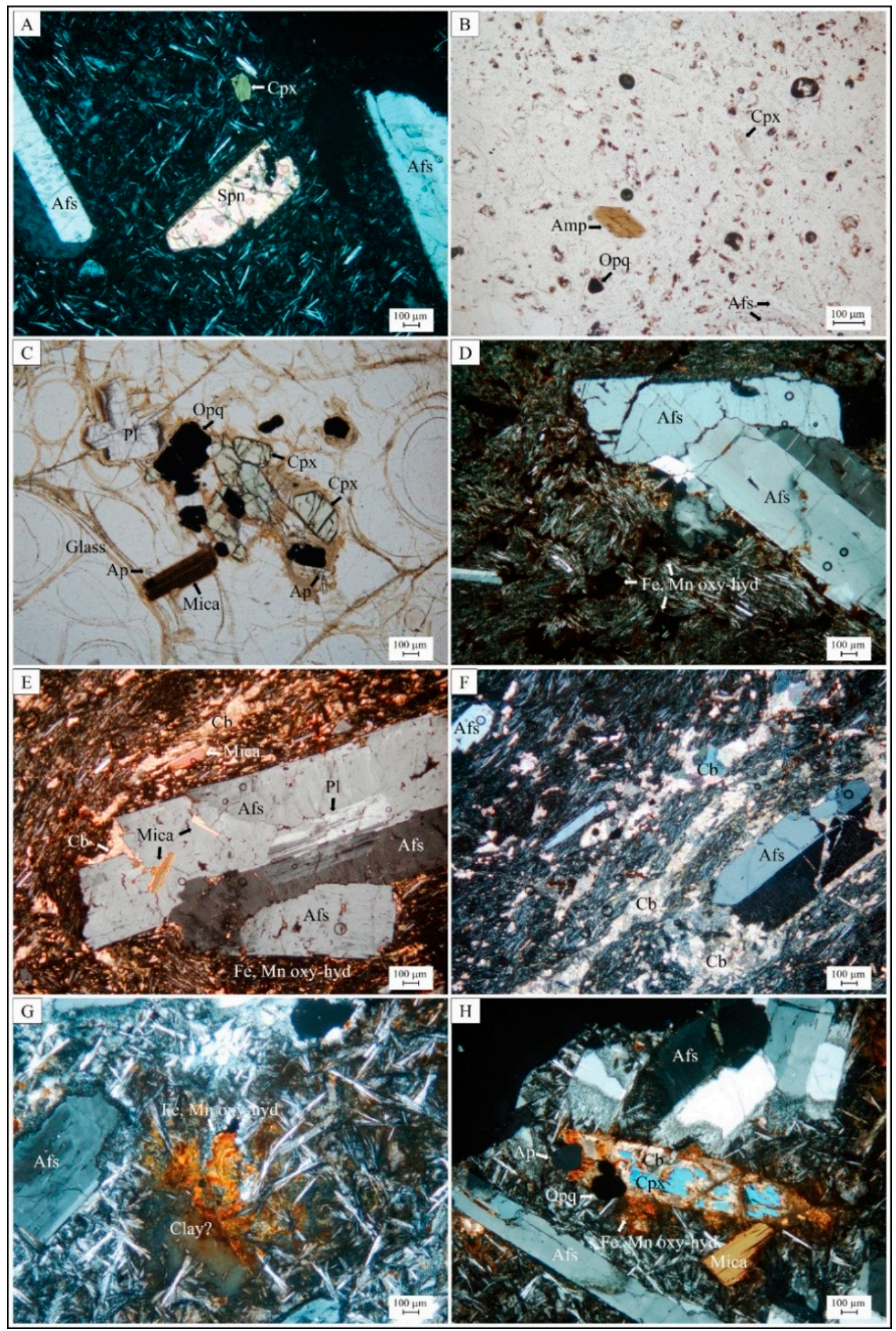

Figure 2. Selected thin section photomicrographs of the investigated MEGT samples; additional photomicrographs are provided in Supplementary Figure S1. Key for mineral names (abbreviated according to Whitney and Evans, 2010 [48], except for Fe, Mn oxy-hydroxides, abbreviated as Fe, Mn oxy-hyd): Afs = alkali-feldspar; $\mathrm{Cpx}=$ clinopyroxene; $\mathrm{Pl}=$ plagioclase; Opq = opaque oxide; $\mathrm{Spn}$ = sphene; $\mathrm{Ap}=$ apatite; $\mathrm{Amp}=$ amphibole; $\mathrm{Cb}=$ carbonate. (A) fresh scoria showing porphyritic texture and microcrystalline/felty groundmass (cross-polarised light; sample OIS0102); (B) fresh scoria showing porphyritic texture and microcrystalline/felty groundmass (plane-polarised light; sample OIS0102); (C) gabbroic agglomerate in vitrophyric obsidian, showing the typical perlitic fractures; in 
the agglomerate, the plagioclase rim is slightly altered (enriched in Fe, see EMPA data in Table S1) and the interstitial glass is partly altered (plane-polarised light; sample MEGT0318); (D) volcanic bomb (scoria) showing porphyritic/glomeroporphyritic texture and microcrystalline/felty/fluidal groundmass with pervasive alteration by $\mathrm{Fe}, \mathrm{Mn}$ oxy-hydroxides patches and veins cutting phenocrysts (cross-polarised light; sample MEGT0302); (E) same sample as D, showing abundant carbonate patches in the groundmass, and a plagioclase phenocryst at the core of an alkali-feldspar phenocryst (cross-polarised light; sample MEGT0302); (F) same sample as D, showing a thick carbonate vein cutting a large alkali-feldspar phenocryst (cross-polarised light; sample MEGT0302); (G) scoria showing porphyritic texture and microcrystalline/felty groundmass with pervasive alteration by patches of Fe, Mn oxy-hydroxides, and perhaps clays; the alkali-feldspar phenocryst on the left side is partly corroded by alteration (cross-polarised light; sample MEGT0301); (H) same sample as G, showing an agglomerate made up of dominant alkali-feldspar and clinopyroxene, and minor black mica, opaque oxide, and apatite; the clinopyroxene phenocryst is almost totally replaced by carbonate and $\mathrm{Fe}, \mathrm{Mn}$ oxy-hydroxides; the alkali-feldspar phenocrysts exhibit a comb texture, suggesting that alteration has proceeded from rim toward the inner part (cross-polarised light; sample MEGT0301).

\subsection{Primary Minerals}

\subsubsection{Feldspars}

Alkali-feldspar occurs in all analysed MEGT samples, whereas plagioclase coexists with alkali-feldspar in a few samples only (MEGT0318, MEGT0322). Alkali-feldspar is widely variable (Figure 3 and Supplementary Table S1) from quasi-pure sanidine $\left(\mathrm{Or}_{98-89} \mathrm{Ab}_{2-11}\right)$, through sanidine $\left(\mathrm{Or}_{72-53} \mathrm{Ab}_{25-43}\right)$, Na-sanidine $\left(\mathrm{Or}_{54-32} \mathrm{Ab}_{42-57}\right)$, to anorthoclase $\left(\mathrm{Or}_{35-18} \mathrm{Ab}_{58-65}\right)$. However, plagioclase, where present, varies only within the field of andesine $\left(\mathrm{An}_{44-31} \mathrm{Ab}_{48-60}\right)$ (Figure 3 and Supplementary Table S1), except for one oligoclase $\left(\mathrm{An}_{24} \mathrm{Ab}_{64}\right)$ crystal. Quasi-pure sanidine occurs as either rims or recrystallisation overgrowth with a peculiar comb-texture of alkali-feldspar and plagioclase phenocrysts (Figure $2 \mathrm{H})$. One feldspar microlite is quasi-pure albite $\left(\mathrm{Or}_{3} \mathrm{Ab}_{95}\right)$. Reverse zoning is very common in both plagioclase and alkali-feldspar phenocrysts; moreover, crystals with andesine cores and a thick rim of alkali-feldspar are common (Figure 2E). In altered samples, the plagioclase and alkali-feldspar phenocrysts are cut by carbonate veins (Figure 2F).

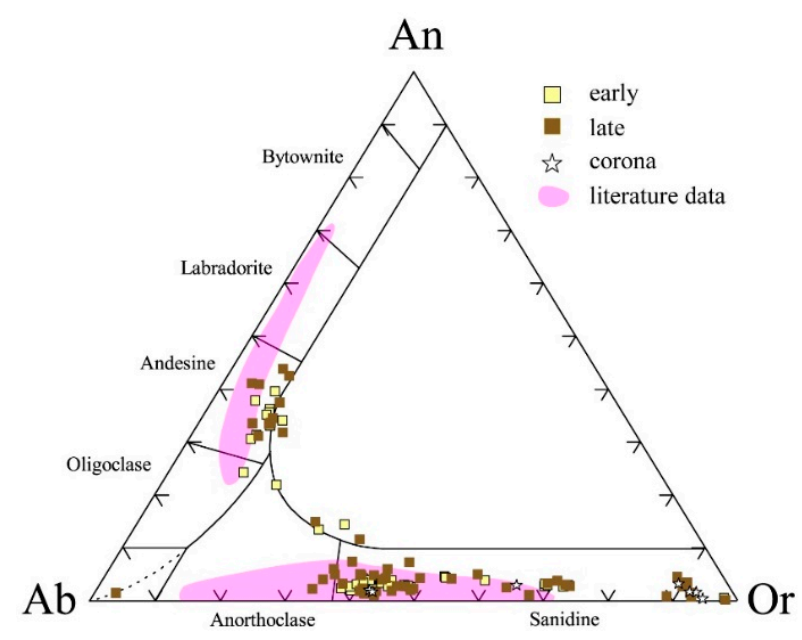

Figure 3. Ternary classification diagram Ab-An-Or for feldspars [49] showing all plagioclase and alkali-feldspar crystals analysed in the selected MEGT volcanic rocks. Ab = albite molar $\%$, including Sr-feldspar; An = anorthite molar \%; Or = orthoclase molar \%, including celsian. Early = phenocryst core; late = phenocryst rim, microphenocrysts and groundmass microlites; overgrowth on phenocryst. The pink fields are drawn using mineral chemistry data on Ischia trachytes and phonolites from the literature $[14,19,41,43]$. 


\subsubsection{Clinopyroxene}

According to the IMA 1990 pyroxene nomenclature scheme ([50] and references therein), all analysed clinopyroxenes are ferroan diopside (Figure 4A and Supplementary Table S1; common modifier names are: ferroan, ferrian, aluminian; rarely sodian). In terms of relative En and Fs contents, they are moderately variable, from $\mathrm{En}_{45} \mathrm{Fs}_{7}$ to $\mathrm{En}_{29} \mathrm{Fs}_{27}$; $\mathrm{Mg \#} \mathrm{(magnesium} \mathrm{number:} \mathrm{atomic} 100 \times \mathrm{Mg} / \mathrm{Mg}+\mathrm{Fe}_{\text {tot }}+\mathrm{Mn}$ ) varies in the range 86-53. The Wo content slightly decreases from 48 to 45 with increasing Fs content, following an evolution trend detected typically in clinopyroxene from Ischia evolved volcanic rocks ([41]; see also Discussion). The only clinopyroxene with a composition approaching that of diopside $(\mathrm{Mg \#}=86)$ has been found as the rim of a reversely zoned phenocryst. Indeed, reverse zoning is common. In several samples, clinopyroxene is partly or totally replaced by carbonate $\pm \mathrm{Fe}, \mathrm{Mn}$-oxy-hydroxides (Figure $2 \mathrm{H}$ ). Clinopyroxene phenocrysts and fragments handpicked from two samples of tephra layers occurring in distal sites were analysed using the same facility and techniques as those employed for MEGT proximal samples (Figure 4B). The comparison between the composition of clinopyroxene from proximal and distal outcrops will be discussed later.

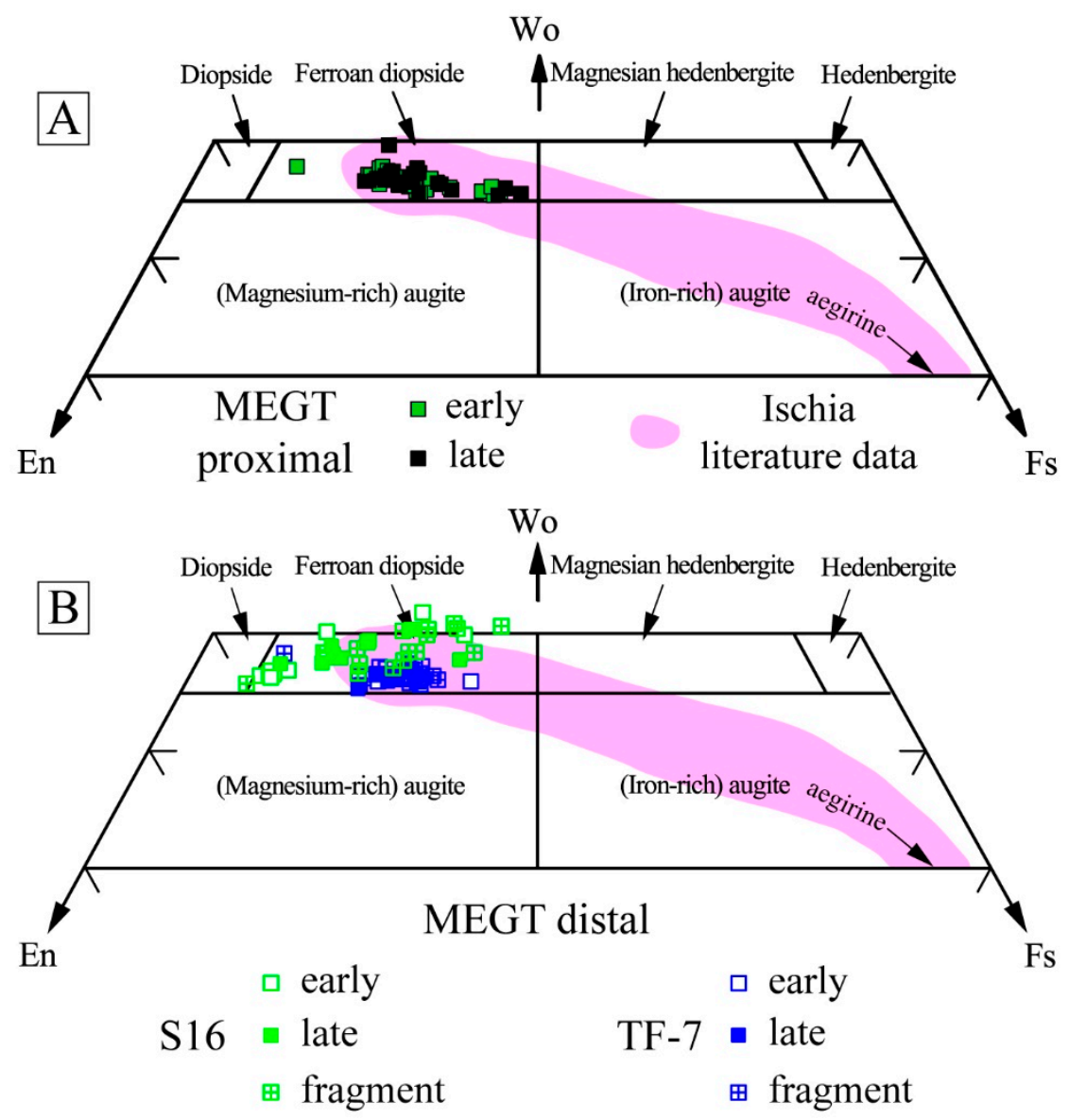

Figure 4. Pyroxene quadrilateral classification diagram Di-Hd-En-Fs [51]. (A) clinopyroxene crystals analysed in the selected MEGT volcanic rocks. The pink field has been drawn using mineral chemistry data on Ischia trachytes and phonolites from the literature $[14,19,41,43]$. (B) clinopyroxene crystals and fragments separated from samples S16 [7,8] and TF-7 [2]. See Discussion for details. Early $=$ phenocryst core; late $=$ phenocryst rim, microphenocrysts and microlites; fragment $=$ broken crystal for which it is not possible to ascertain the original shape.

\subsubsection{Black Mica}

According to the IMA 1998 nomenclature scheme ([52] and references therein), the common black mica which occurs in all analysed samples classifies as ferrian phlogo- 
pite (corresponding to Mg-biotite, as disapproved IMA name). Its composition is quasihomogeneous (Supplementary Table S1), with $\mathrm{Mg} \#\left(=\left[\mathrm{Mg} /\left(\mathrm{Mg}+\mathrm{Fe}^{2+}+\mathrm{Fe}^{3+}\right]\right)\right.$ in the range $0.69-0.66$. The fluorine content is between 0.5 and $3.3 \mathrm{wt} \%$.

\subsubsection{Opaque Oxides}

Ti-magnetite is the only opaque oxide mineral phase occurring as accessory microphenocrysts in all analysed MEGT samples. Its ulvöspinel content (calculated according to Stormer, 1983 [53], using the software ILMAT 2.0 by Lepage, 2003 [54]) varies in the range 22-40\% (Figure 5; Supplementary Table S1).

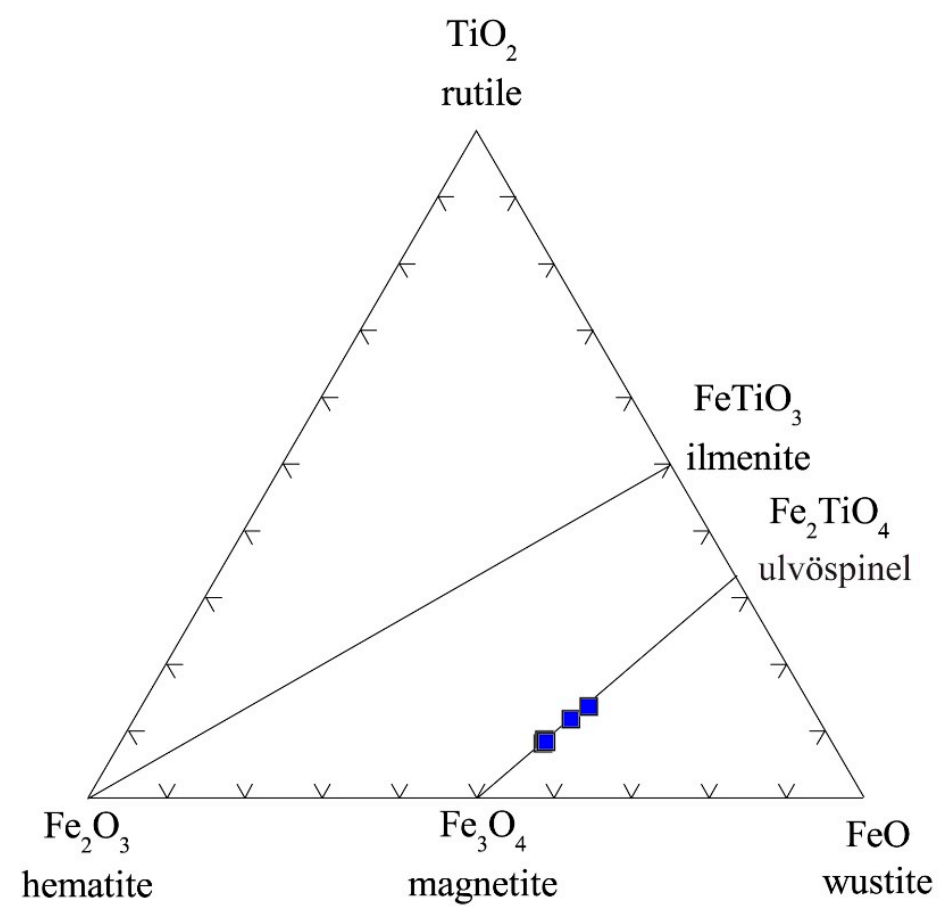

Figure 5. $\mathrm{Fe}_{2} \mathrm{O}_{3}-\mathrm{TiO}_{2}-\mathrm{FeO}$ ternary diagram [53] for opaque oxides of the selected MEGT volcanic rocks.

\subsubsection{Other Accessory Phases}

Sphene-Phenocrysts and micro-phenocrysts of sphene are common in the groundmass and sometimes within alkali-feldspar phenocrysts of fresh MEGT samples. Their EMP analysis (Supplementary Table S1) reveals significantly high $\mathrm{Al}_{2} \mathrm{O}_{3}(1.2-1.3 \mathrm{wt} \%$ ) and $\mathrm{FeO}$ (1.7-2.9 wt\%) contents, whereas the low closures likely suggest high content of Rare Earth Elements and/or High Field Strength Elements, not determined by EMPA [49].

Amphibole-Calcic amphibole occurs as rare micro-phenocrysts or microlites (within alkali-feldspar phenocrysts or in the groundmass) in only one, fresh sample (OIS 0102). According to the IMA-04 amphibole nomenclature scheme ([55] and references therein), it classifies as edenite (modifier names are fluorian, potassian, manganoan, titanian), with $\mathrm{Mg \#}$ (atomic $\mathrm{Mg} / \mathrm{Mg}+\mathrm{Fe}^{2+}$ ) in the range 0.64-0.51 (Supplementary Table S1).

Apatite-The rare Ca-phosphate microlites occurring in the MEGT samples have relatively high F contents and low EMPA closures (Supplementary Table S1), suggesting a high content of water in their lattice; therefore, they can be classified as hydroxy-fluorapatite [49].

\subsection{Secondary Minerals and Groundmass Glass}

Secondary minerals are common in most analysed MEGT samples due to intense hydrothermal alteration (see also Di Napoli et al., 2013 [12]). Secondary alkali-feldspars, occurring as either quasi-pure sanidine (in most cases) or rare quasi-pure albite, have 
already been described in Section 4.1.1. Their composition expands the range of fresh primary feldspars. Additional secondary minerals are described in the following.

\subsubsection{Carbonate}

Carbonate is common in almost all analysed samples with variable abundance. It occurs as both veins cutting phenocrysts (Figure 2F) and patches in the groundmass (Figure 2H); in some samples, it partially replaces clinopyroxene phenocrysts (Figure $2 \mathrm{H}$ ). The composition shows limited variation from quasi-pure $\mathrm{CaCO}_{3}$ to carbonates with up to $\approx 10 \mathrm{wt} \%$ of other components, mostly $[\mathrm{Fe}+\mathrm{Mn}] \mathrm{CO}_{3}$ and subordinately $\mathrm{MgCO}_{3}$ (Figure 6 and Supplementary Table S1).

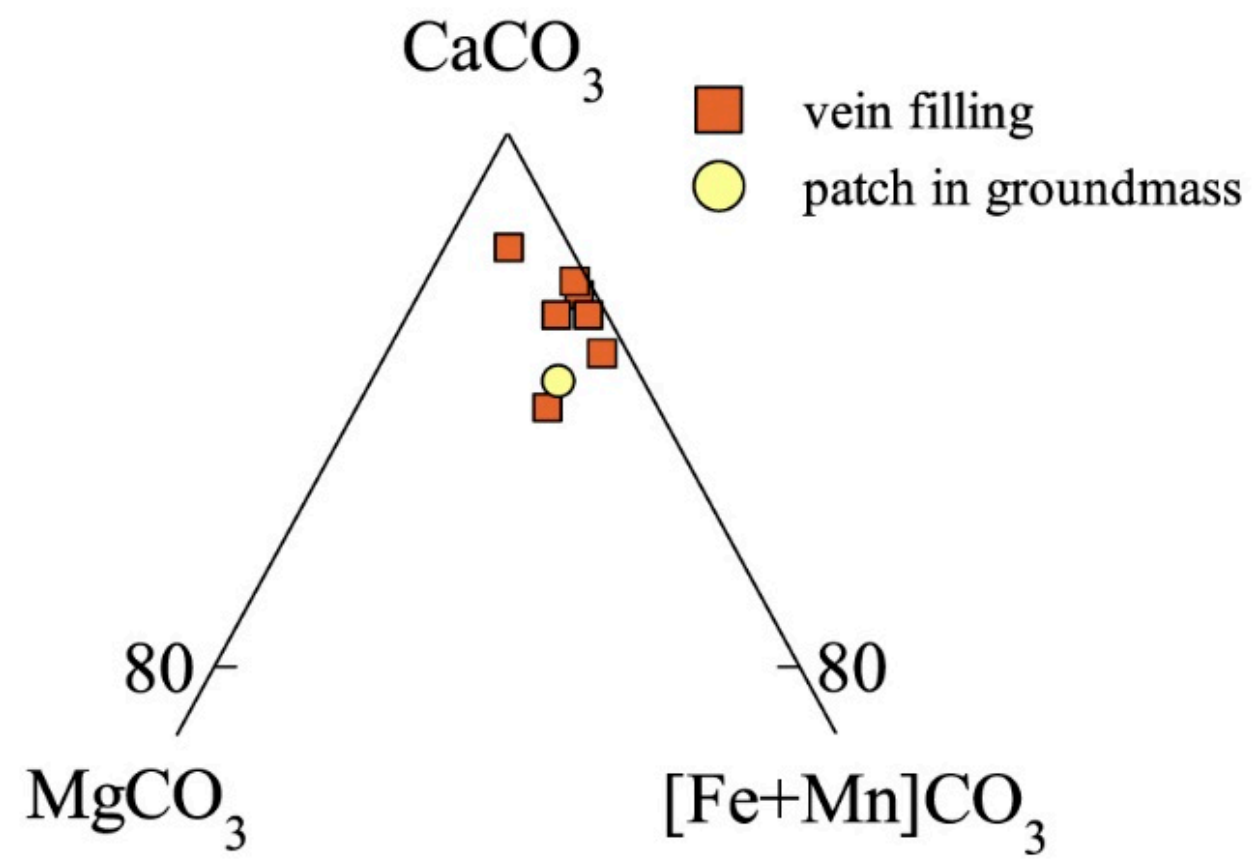

Figure 6. $\mathrm{MgCO}_{3}-\mathrm{CaCO}_{3}-[\mathrm{Fe}+\mathrm{Mn}] \mathrm{CO}_{3}$ ternary diagram for carbonates of the selected MEGT volcanic rocks.

\subsubsection{Iddingsite/Clay Minerals}

Patches of "iddingsite" (i.e., mixtures of clay minerals and iron-manganese oxyhydroxides) are observed in thin sections in the altered MEGT samples. Only two EMP analyses have been successfully performed and resulted in variably silica depleted and iron and magnesium enriched (in one case also Mn; Supplementary Table S1). An X-rays diffraction investigation on MEGT samples reports the presence of randomly interstratified illite/smectite, Fe-illite and smectite [56].

\subsubsection{Glass, Altered Glass, and Zeolites}

Fresh groundmass glass has a composition that varies from trachyte to phonolite (Figure 7 and Supplementary Table S1) and is quite comparable with that of MEGT, which is variable from trachyte to phonolite too, and other, slightly less evolved, whole-rock samples of 75-55 ka age [11,15]. When altered, the glass shows selective loss of variable amounts of $\mathrm{Na}, \mathrm{K}, \mathrm{Fe}$, and $\mathrm{Mg}$. The resulting EMP analyses carried out on these altered patches of the groundmass were suspected to be zeolites (Supplementary Table S1); however, none matches any known, common Ca-K-Na-zeolite (i.e., phillipsite, erionite, stilbite and mordenite) composition. Only one analcite patch has been detected in the groundmass of an altered sample. The occurrence of phillipsite, chabazite, and analcite in the MEGT has been reported based on X-ray diffraction studies [56]. 


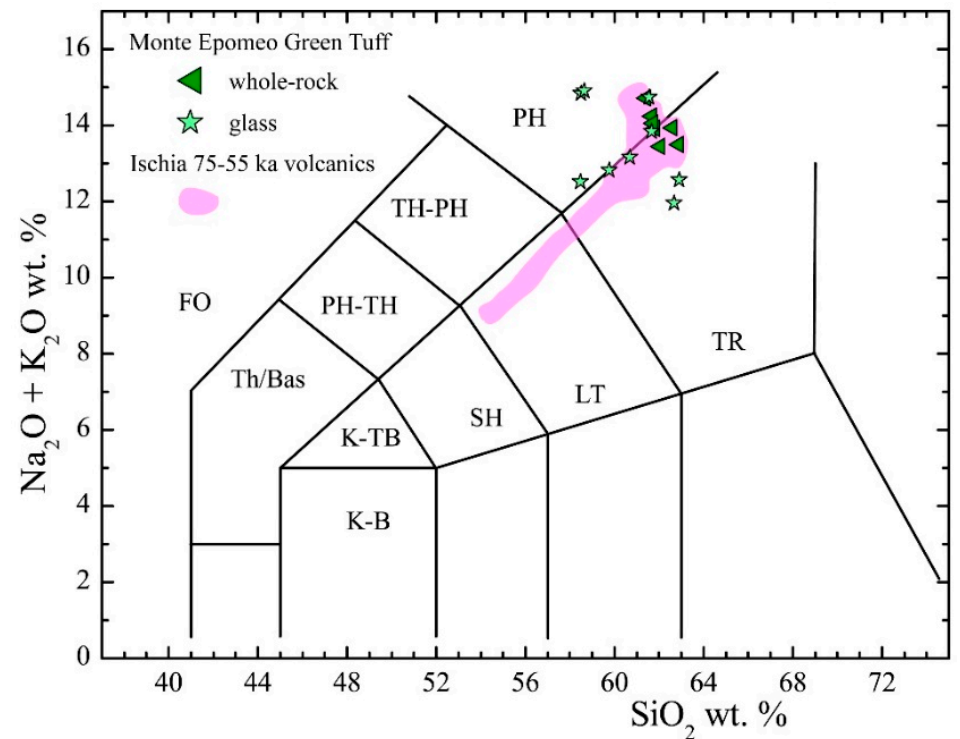

Figure 7. Total alkali vs. silica classification diagram (TAS; [57]) showing the composition of apparently fresh glass analysed in MEGT volcanic rocks (this work; data from Supplementary Table S1), compared with whole rock data on MEGT and 75-55 ka Ischia volcanic rocks from the literature [11,15]. All analyses were plotted after normalisation to $100 \%$ on a water-free basis, according to recommendation by I.U.G.S. [57]. K-B = potassic basalt; K-TB = potassic trachybasalt; $\mathrm{SH}=$ shoshonite; $\mathrm{LT}=$ latite; $\mathrm{TR}=$ trachyte (these rock names are relative to a potassic alkaline series); $\mathrm{TH} / \mathrm{Bas}=$ tephrite/basanite; $\mathrm{PH}-\mathrm{TH}=$ phonotephrite; $\mathrm{TH}-\mathrm{PH}=$ tephriphonolite; $\mathrm{PH}=$ phonolite.

\section{Discussion}

\subsection{Distal Occurrences of Ischia Tephra in the 60-55 ka Time Span}

The analytical data presented for samples representative of the Monte Epomeo Green Tuff of Ischia allow a thorough characterisation of the main petrographic textures and the mineral assemblage. The most abundant primary mineral phases occurring as phenocrysts and micro-phenocrysts are alkali feldspar, which is variable from sanidine to anorthoclase, followed by plagioclase (mostly andesine) and ferroan diopside, with minor amounts of ferrian phlogopite and titano-magnetite. Accessory mineral phases include sphene, sometimes occurring as phenocrysts, hydroxy-fluor-apatite, and rare edenitic amphibole. All mineral phases also occur as microlites; accessory phases are mostly confined to the groundmass. Secondary minerals, related to pervasive post-eruption hydrothermal alteration that affected the intracaldera deposits, include alkali-feldspar from quasi-pure sanidine to rare, quasi-pure albite, calcium carbonate, iddingsite, clay minerals, and zeolites. Secondary alkali-feldspar occurs mostly as pervasive re-crystallisation at the expense of primary phenocrysts, forming an unusual comb texture (Figure $2 \mathrm{H}$ ). Given the evolved chemical character of host whole rocks (trachyte-phonolite), as well as of the coexisting Na-rich plagioclase, the most K-rich varieties of alkali-feldspar $\left(\mathrm{Or}_{98-89} \mathrm{Ab}_{2-11}\right)$ are thought to be adularia, which is formed by a preferential loss of $\mathrm{Na}$ that may successively precipitate as analcite (e.g., [58]). The precipitation of secondary, quasi-pure sanidine and/or albite is not uncommon for igneous rocks that encounter either hydrothermal fluids or seawater (e.g., [59-62]). The quasi-pure albite $\left(\mathrm{Or}_{3} \mathrm{Ab}_{95}\right)$ microlite is likely a result of alteration, too (albitisation). Calcium carbonate occurs as either thin veins and patches or a pervasive pseudomorphic substitution of clinopyroxene phenocrysts. Iddingsite, clay minerals, and zeolites are present as either a partial replacement of mafic phases or patches in the groundmass. Interestingly, carbonate was not observed by Altaner et al. (2013) [56] in either optical microscopy or scanning electron microscopy observations of MEGT samples, despite detection through $\mathrm{X}$-ray diffraction; the authors instead identified various clay minerals (illite/smectite, Fe-illite, and smectite) and zeolites (phillipsite, chabazite, and analcite). 
The mineral-chemical characterisation presented here helps clarify correlations with reported distal MEGT ash layers, some of which have served as stratigraphic tephra markers in the central Mediterranean for decades. Keller et al. (1978) [23] reported on a peculiar trachytic tephra, named Y-7, which was found in three southeastern Mediterranean deep-sea bore holes (circles 13, 14, and 16 in Figure 1B), and characterised by abundant Na-rich yellow pyroxene, in addition to aegirin-augite, biotite, apatite, sphene, zircon, plagioclase, and sanidine (the "acmite-trachyte layer"). Based on its unique petrography and chemistry $\left(\mathrm{Na}_{2} \mathrm{O}>\mathrm{K}_{2} \mathrm{O}\right)$ that is distinct from other trachytic tephra layers of Campania $\left(\mathrm{K}_{2} \mathrm{O}>\mathrm{Na}_{2} \mathrm{O}\right)$, the authors postulated an origin from Ischia (the "San Angelo tuffs" of Rittmann, 1930 [63]; see also Brown et al., 2008 [15]). Other studies referred to the Y-7 layer and to other stratigraphically equivalent tephra layers in both continental and deep-sea sequences, as the distal counterpart of MEGT, implicitly acknowledging that the MEGT products have aegirine as a distinctive petrographic feature.

Within the time span between $60.3 \pm 2.2$ and $51.0 \pm 2.2 \mathrm{ka}$ (astronomically tuned), Paterne et al. (1988) [3] identified three peralkaline trachytic distal tephra layers, labelled C-18, C-17, and C-16, in deep-sea cores from the Tyrrhenian Sea (KET 8003, KET 8004, KET 8011, KET 8022) and southern Adriatic Sea (KET 8218). C-18, dated at $60.3 \pm 2.2 \mathrm{ka}$, is the thickest and most widespread, and they tentatively correlated it with the Y-7 tephra. However, they noted that no large volume deposit of that composition and age has been recognised on-land at either Ischia or Campi Flegrei; conversely, the $\approx 55 \mathrm{ka}$ C-17 and $\approx 51 \mathrm{ka} \mathrm{C}-16$ tephra layers were attributed to the MEGT and Barano eruptions of Ischia, respectively, with $\mathrm{C}-17$ being chronologically fully consistent with radioisotopic age of the MEGT at ca. 55-56 ka [1,2]. Unfortunately, Paterne et al. (1988) [3] did not report mineralogical data for the studied distal ashes, so it is not possible to know whether Naclinopyroxene was present in any tephra layers they attributed to Ischia. Based on the major element glass composition, the authors attributed all three tephra layersto the 60-51 ka "Green Tuff Series". In the deep-sea core extracted from Site 650 in the central Tyrrhenian Sea during Ocean Drilling Program Leg 107, Calanchi et al. (1994) [21] correlated the tephra T 003 to both Y-7 and C-18. The correlation was supported by major element glass composition; unfortunately, no petrographic description was provided.

Narcisi (1996) [4] described a >34 cm-thick tephra layer, L14, from the Lago Grande di Monticchio (circle 4 in Figure 1B) lacustrine sequence as trachytic in composition with only sanidine as a mineral phase dispersed among the glass shards. The author attributed L14 to the MEGT, based on its stratigraphic position and major oxide chemistry, without referring to the Y-7 layer of Keller et al. (1978) [23]. Later, the same Lago Grande di Monticchio layer, re-labelled as MT-9, was correlated by Allen et al. (1999) [63,64] to the Y-7 Mediterranean marine tephra and attributed to Ischia. The authors reported also a ${ }^{40} \mathrm{Ar} /{ }^{39} \mathrm{Ar}$ age for this layer of 56,000 $\pm 4000 \mathrm{ka}$ made by Kraml (1997) [65], which is close to the K-Ar age of $55 \pm 3.5 \mathrm{ka}$ available for the MEGT on the island [1]. Narcisi and Vezzoli (1999) [66] instead attributed an age of $50 \mathrm{ka}$ to $\mathrm{Y}-7$, according to its stratigraphic position constrained by sapropel layers, pointing out that its on-land counterpart was still undefined. In a detailed tephrochronological study of the Lago Grande di Monticchio lacustrine sequence, Wulf et al. (2004) [6] renamed the L14 layer of Narcisi (1996) [4] as TM-19, reporting a varvesupported age of $\approx 56,250$ yrs BP and attributing it to the MEGT. Conversely, layer TM-20, lying immediately below TM-19 and with a varve age of 57,570 yrs BP, was tentatively attributed to the "Monte Sant'Angelo Unit", which was generated during an initial phase of the MEGT eruption according to stratigraphic correlations among proximal deposits made by Rosi et al. (1988) [67]. Wulf et al. (2004) [6] described TM-20 as having a similar peralkaline trachytic composition as TM-19 but distinguished by the occurrence of sphene and abundant aegirine (= acmite).

In his re-evaluation of previous astronomically tuned timescales for cores from Ocean Drilling Program Leg 160 Site 964 and KC01B in the Ionian Sea (circle 17 in Figure 1B), Lourens (2004) [5] found that the tephra I4 could be correlated to both Y-7 of Keller et al. (1978) [23] and C-17 of Paterne et al. (1988) [3]. However, this correlation was questioned 
by Insinga et al. (2014) [24] using major oxides arguments, leaving open the possibility that I4 could have been generated from a volcanic source located either at Ischia in a time very close to the MEGT or in the Campi Flegrei area.

Bourne et al. (2010) [20] investigated tephra layers recovered from core PRAD 1-2 in the central Adriatic Sea (circle 1 in Figure 1B). Among them, the cryptotephra PRAD 1870 was found to be chemically comparable to layers TM-19, TM-20, and TM-20-1 from the Lago Grande di Monticchio sequence. On that basis, the authors claimed that PRAD 1870 represents a product of the MEGT eruption and thus is likely correlated with the Y-7 tephra. That correlation implies that the MEGT deposit should have sodic clinopyroxene as a distinctive mineralogical feature, which is not supported by our findings. Ambiguity in the attribution of distal ash layers to the MEGT and other Ischia deposits of similar age reported in the previous literature was also pointed out by Brown et al. (2008) [15], who re-defined 75-50 ka old proximal pyroclastic deposits of Ischia, and by Tomlinson et al. (2014) [9]. The latter authors carried out a detailed geochemical characterisation of volcanic deposits emplaced at Ischia in the 75-39 ka time span, including the MEGT, and of distal tephra layers considered as equivalent of either MEGT or other older and younger deposits. They concluded that the most likely distal correlatives of MEGT, which share closely similar major oxides and trace elements features, are as follows: the cryptotephra PRAD 1870 from core PRAD 1-2 in central Adriatic Sea (circle 1 in Figure 1B); the tephra TM-19 from Lago Grande di Monticchio sequence (circle 4 in Figure 1B); the so-called "Ischia Tephra" found embedded within pyroclastic layers on the island of Stromboli in southern Tyrrhenian Sea (circle 12 in Figure 1B); the tephra MD28 from core MD01_2474G to the north of Stromboli [68]; the tephra Y-7 from M25/4-11, V10-68, RC9-191, and RC9-190 bore holes in the Ionian Sea (circles 13-16 in Figure 1B). Moreover, Tomlinson et al. (2014) [9] disputed the correlation of tephra S15 from San Gregorio Magno sequence (circle 5 in Figure 1B) with MEGT and even its attribution to Ischia but confirmed the correlation of S16 with MEGT postulated by Munno and Petrosino (2007) [7]. Thus, Tomlinson et al. (2014) [9] pointed out a very good geochemical match among all these distal tephra layers, hypothesising that all of them are distal equivalents of the MEGT; however, they did not carry out a comparison of their mineralogical features.

\subsection{Clinopyroxene Analysis as a Tool to Identify the Ischia Distal Tephra in the 60-55 ka Time Span}

It is of interest that sodic clinopyroxene i.e., aegirine (= acmite) has never been reported as a phenocryst phase in any pyroclastic rocks on Ischia [11,12,14,19,25,38,39,66]; rather, some authors said that clinopyroxene tends to be more enriched in the aegirinic component in the most evolved Ischia lavas, where it occurs as Na-rich microlites in the groundmass only [14,41]. For instance, Poli et al. (1987) [14], who subdivided the volcanic activity of Ischia into four phases, say that aegirine is present in the products of the second volcanic activity phase only, between 150 and $75 \mathrm{ka}$, which are the most evolved ones and occur mostly as lava domes; however, in that work, it is not specified whether or not aegirine occurs as a phenocryst phase. Poli et al. (1987) [14] and Vezzoli (1988) [26] published two EMP analyses of sodic clinopyroxene, without specifying whether they analysed phenocrysts or microlites, lavas or pyroclastic rocks. Interestingly, Poli et al. (1987, 1989) [14,32] and Vezzoli (1988) [26] did not recognise a volcanic activity in the 75-55 kyr time span at Ischia, stating that the MEGT eruption opened a new cycle after $20 \mathrm{kyr}$ of quiescence. Brown et al. (2008) [15] instead highlighted that a significant, mostly explosive volcanic activity occurred at Ischia since $75 \mathrm{ka}$ until the MEGT eruption. In the products related to this newly recognised phase of activity, sodic clinopyroxene phenocrysts were not documented. Melluso et al. (2014) [41] reported on the occurrence of aegirine-rich clinopyroxene in extremely differentiated lavas belonging to all volcanic cycles at Ischia, although exclusively confined to the groundmass. According to the authors, Ti-Zr-rich aegirine appears along with Mn-aenigmatite and several exotic mineral phases (låvenite, rinkite, kochite, hiortdahlite, hainite and britholite) in the crystallised groundmass of Ischia trachyphonolitic lavas when the residual magma reaches a clear peralkalinity. 
The most recent tephrostratigraphical and tephrochronological evidence for the occurrence of $\mathrm{Y}-7$ in continental sites are the lacustrine successions of the Fucino basin located in Abruzzo, central Italy (circle 3 in Figure 1B), where the marker has been precisely dated [2], and the San Gregorio Magno basin located in Campania (circle 5 in Figure 1B) characterised by Munno and Petrosino (2007) [7] and Petrosino et al. (2019) [8]. In order to test the soundness of the clinopyroxene geochemistry as a potential tool for tephra fingerprinting purposes, we selected samples from these two distal tephra layers correlated to MEGT and compared them with crystals analysed in MEGT proximal products (Figure 4). One is sample S16 from the San Gregorio Magno lacustrine succession, which is correlated to the MEGT on the basis of its stratigraphic position as well as the chemical and Sr-Nd isotopic composition of glass and sanidine $[7,8]$. The second sample is TF-7 from the Fucino lacustrine succession, which is well characterised from chemical and $\mathrm{Sr}-\mathrm{Nd}$ isotopic points of view and attributed to the MEGT on the basis of its stratigraphic position and precise ${ }^{40} \mathrm{Ar} /{ }^{39} \mathrm{Ar}$ age of $56.1 \pm 1.0 \mathrm{ka}$ [2].

The comparison reveals that clinopyroxene crystals from the two distal samples match those from the MEGT proximal samples (Figure 4). This is true for sample TF-7, in particular, but it holds also for sample S16, although its clinopyroxene shows more scatter than the former. None of the analysed clinopyroxene crystals have a composition that approaches that of aegirine, which would plot in the lower right side of the iron-rich augite field of the diagram (Figure 4). This implies that aegirine cannot be employed as a distinctive feature for identifying distal tephra layers that correlate to the MEGT, and that the "acmite-trachyte" tephra layer found by Keller et al. (1978) [23] in three cores located in the Ionian Sea (circles 13, 14, and 16 in Figure 1B) and named Y-7, and the equivalent tephra layer of core M25/4-11 (circle 15 in Figure 1B; [9]) are not the MEGT. This has resulted in a misunderstanding in stratigraphic studies and correlations for the Mediterranean area.

According to this result, we attempted an estimate of the areal distribution of MEGT and Y-7 tephra layers, assuming Ischia as a common source, in all the distal occurrences where they can be confidently identified (Figure 8). It is rather evident that the distribution axes are different, NE to E for MEGT and SE for Y-7, which is likely because of the distinct dominant winds during the two explosive events. Moreover, the map illustrates that it is still uncertain if both MEGT and Y-7, or which one of the two tephra layers, occur in several distal sites, such as cores ODP Leg 107 Site 650, KET 8003, KET 8004, KET 8011 and KET 8022 in the Tyrrhenian Sea, core KET 8218 in the Adriatic Sea, and cores ODP Leg 160 Site 964 and KC01B in the Ionian Sea [3,5,21,24]. Considering the available chronological data, layer C-17 is likely the best candidate to be correlated with the MEGT, whereas the slightly older C-18 could represent the equivalent of the Ionian layer Y-7. However, lacking a robust petrographic characterisation and mineral geochemical composition, a definitive attribution to one or the other layer should be avoided. This is particularly true for the circumstances when an Ischia-like tephra layer occurs as an individual layer, i.e., in a stratified succession without more tephra layers. For instance, the layer SU 14 of the Oscurusciuto Palaeolithic site, located in Apulia (circle 6 in Figure 1B; Figure 8) could be correlated to either the 56 ka MEGT tephra or the slightly older, 60 ka Y-7 tephra based on the major element glass composition alone. A definitive correlation could be proposed only through a petrographic and mineral-chemical characterisation. This, and the other mentioned tephra layers in the central Mediterranean area that have some resemblance to Ischia explosive deposits remain unattributed with certainty, leaving the areal distribution and volume estimation of MEGT and Y-7 undefined (Figure 8). The question deserves more investigation.

It is likely that after so many decades, some scientists will continue to call the distal counterpart of the MEGT as Y-7. However, it does not correspond to the Y-7 as originally defined by Keller et al. (1978) [23]. Interestingly, none of the Ischia volcanic deposits close in time to the MEGT has yet been identified as containing sodic clinopyroxene as a phenocryst $[11,15]$. Therefore, the proximal counterpart of the "acmite-trachyte" tephra recognised by Keller et al. (1978) [23] remains unidentified. Mineralogical assemblage 
and mineral chemistry were found to be useful tools to disprove the MEGT/Y-7 possible correlation and can be successfully used in the future to prevent misleading attributions even when the unknown tephra has a glass chemical composition fully comparable with Y-7.

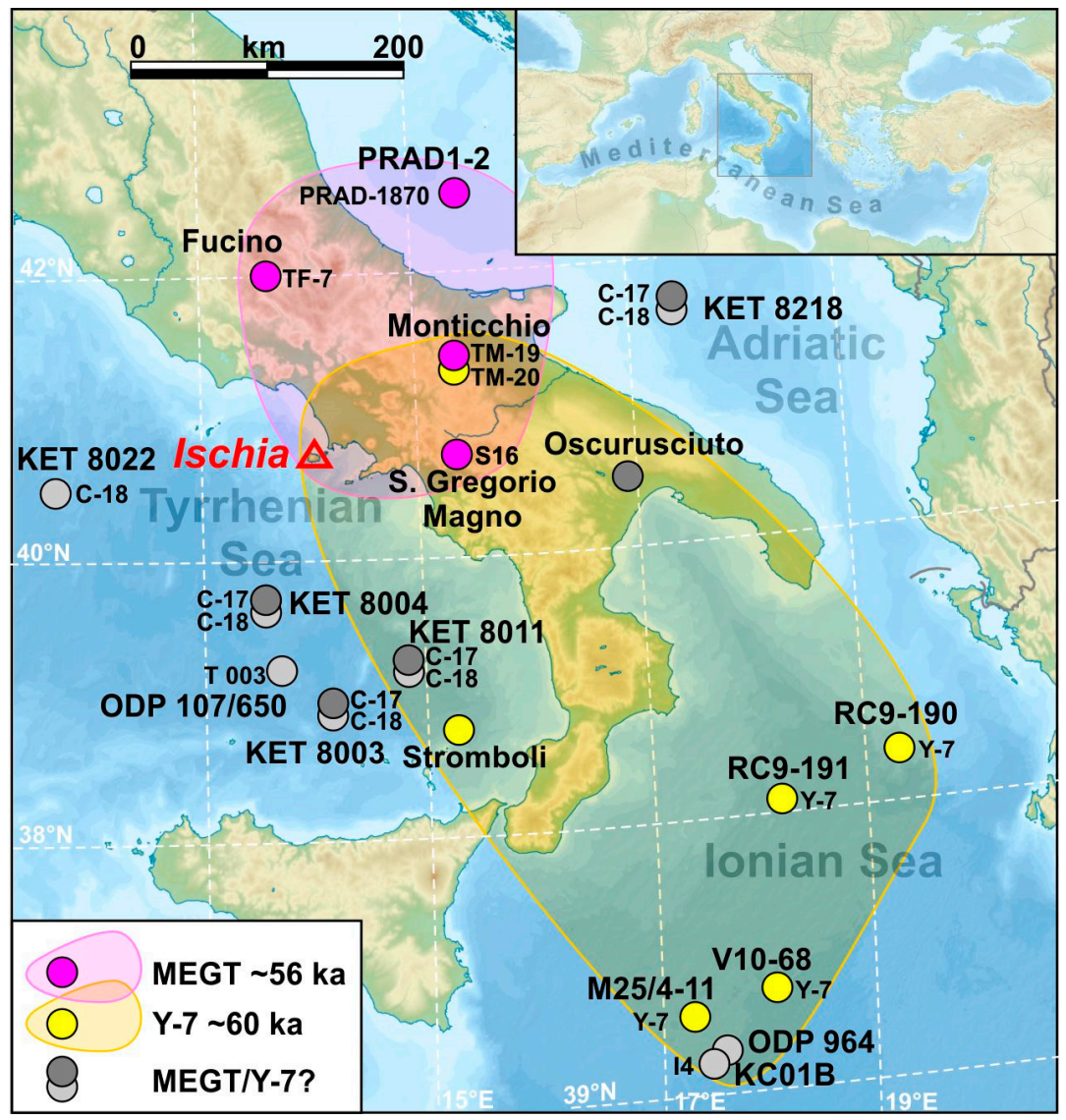

Figure 8. Occurrence of the Monte Epomeo Green Tuff distal tephra, the marine Ischia tephra Y-7, and other "Ischia layers" corresponding to either MEGT or Y-7 or both tephra layers, but still not definitively correlated. Data sources: PRAD 1-2 [20]; Fucino [2]; Lago Grande di Monticchio [6]; San Gregorio Magno [7,8]; Oscurusciuto [10]; KET 8004, KET 8011, KET 8003, KET 8218 [3]; ODP Leg 107 Site 650 [21]; RC9-190, RC9-191, and V10-68 [23]; Stromboli [22]; M25/4-11 [9]; ODP Leg 160 Site 964, KC01B [5,24].

\section{Conclusions}

A detailed petrographic and mineral-chemical investigation on representative rock samples collected from Monte Epomeo Green Tuff eruptive units on Ischia island have allowed us to precisely characterise the deposit. Comparison with mineralogical descriptions of distal tephra layers attributed to the MEGT raises doubts as to whether some of those tephra layers correlate to the MEGT. In particular, the ferroan diopsidic composition of clinopyroxene ( $\left.\mathrm{En}_{45-29} \mathrm{Fs}_{7-27}\right)$ and absence of aegirine (acmite) in the samples analysed here rule out correlations with the Y-7 tephra layer identified in some deep cores of the Ionian Sea by Keller et al. (1978) [23] and Tomlinson et al. (2014) [9] and possibly other tephras characterised by the occurrence of aegirine, such as the "Ischia Tephra" of Stromboli. Instead, other tephra layers with overall geochemical and mineralogical features, though lacking aegirine, similar to the proximal deposits of MEGT, such as TF-7 from Fucino and S16 from San Gregorio Magno lacustrine sequences, can be confidently attributed to the MEGT. Conversely, for a number of occurrences of tephra layers stratigraphically, chronologically, and chemically compatible with either MEGT or Y-7 or both tephra, a definitive attribution is currently prevented by the lack of detailed geochemical data and/or petrographic characterisations. In this regard, this study demonstrates that petrographic and 
mineral-chemical characterisations can be a useful additional tool for identifying tephra layers in distal archives and how they could be diriment for confidentially discriminating the two Ischia tephra markers.

Supplementary Materials: The following are available online at https://www.mdpi.com/article/ 10.3390/min11090955/s1, Figure S1: Additional thin section photomicrographs of investigated MEGT samples, Table S1: Representative EMPA data for the main mineral and glass phases of the investigated MEGT samples.

Author Contributions: M.D. and I.A. conceptualised the work; R.J.B., P.P. and B.G. provided the samples; M.D., P.P. and C.P. made EMP analyses; M.D. wrote the original draft; writing-review and editing were done by all authors; funding acquisition, M.D. All authors have read and agreed to the published version of the manuscript.

Funding: This research was funded partly by Italian Istituto Nazionale di Geofisica e VulcanologiaDipartimento della Protezione Civile, Project V3_3/03 “V3_3-Ischia" 2004-2006, and partly by Italian Ministry of University and Research, Project PRIN 2017 “FUTURE” (N 20177TKBXZ_004) to M.D.

Data Availability Statement: The data presented in this study are partly available in supplementary Table S1; all other data are available on request from the corresponding author.

Acknowledgments: Rossella Di Napoli (University of Palermo, Italy) and Andrea Cavallo (now at CERTEMA technological laboratory, Grosseto, Italy) are warmly thanked for their assistance and technical support, respectively, during EMP analysis. The manuscript benefitted from the constructive comments by three anonymous reviewers.

Conflicts of Interest: The authors declare no conflict of interest.

\section{References}

1. Gillot, P.Y.; Chiesa, S.; Pasquaré, G.; Vezzoli, L. $<30,000 \mathrm{yr}$ K/Ar dating of the volcano-tectonic horst of the isle of Ischia, Gulf of Naples. Nature 1982, 229, 242-245. [CrossRef]

2. Giaccio, B.; Niespolo, E.M.; Alison Pereira, A.; Nomade, S.; Renne, P.R.; Albert, P.G.; Arienzo, I.; Regattieri, E.; Wagner, B.; Zanchetta, G.; et al. First integrated tephrochronological record for the last $190 \mathrm{kyr}$ from the Fucino Quaternary lacustrine succession, central Italy. Quat. Sci. Rev. 2017, 158, 211-234. [CrossRef]

3. Paterne, M.; Guichard, F.; Labeyrie, J. Explosive activity of the south Italian volcanoes during the past 80,000 years as determined by marine tephrochronology. J. Volcanol. Geotherm. Res. 1988, 34, 153-172. [CrossRef]

4. Narcisi, B. Tephrochronology of a late Quaternary lacustrine record from the Monticchio maar (Vulture volcano, southern Italy). Quat. Sci. Rev. 1996, 15, 155-165. [CrossRef]

5. Lourens, L.J. Revised tuning of Ocean Drilling Program Site 964 and KC01B (Mediterranean) and implications for the $\delta^{18} \mathrm{O}$, tephra, calcareous nannofossil, and geomagnetic reversal chronologies of the past 1.1 Myr. Paleoceanography 2004, 19, PA3010. [CrossRef]

6. Wulf, S.; Kraml, M.; Brauer, A.; Keller, J.; Negendank, J.F.W. Tephrochronology of the 100 ka lacustrine sediment record of Lago Grande di Monticchio (southern Italy). Quat. Int. 2004, 122, 7-30. [CrossRef]

7. Munno, R.; Petrosino, P. The Late Quaternary tephrostratigraphical record of the San Gregorio Magno basin (southern Italy). J. Quat. Sci. 2007, 22, 247-266. [CrossRef]

8. Petrosino, P.; Arienzo, I.; Mazzeo, F.C.; Natale, J.; Petrelli, M.; Milia, A.; Perugini, D.; D’Antonio, M. The San Gregorio Magno lacustrine basin (Campania, Southern Italy): Improved characterization of the tephrostratigraphic markers based on trace elements and isotopic data. J. Quat. Sci. 2019, 34, 393-404. [CrossRef]

9. Tomlinson, E.L.; Albert, P.G.; Wulf, S.; Brown, R.J.; Smith, V.C.; Keller, J.; Orsi, G.; Bourne, A.J.; Menzies, M.A. Age and geochemistry of tephra layers from Ischia, Italy: Constraints from proximal-distal correlations with Lago Grande di Monticchio. J. Volcanol. Geotherm. Res. 2014, 287, 22-39. [CrossRef]

10. Marciani, G.; Spagnolo, V.; Martini, I.; Casagli, A.; Sulpizio, R.; Aureli, D.; Boscato, P.; Ronchitelli, A.; Boschin, F. Neanderthal occupation during the tephra fall-out: Technical and hunting behaviours, sedimentology and settlement patterns in SU 14 of Oscurusciuto rock shelter (Ginosa, southern Italy). Archaeol. Anthropol. Sci. 2020, 12, 152. [CrossRef]

11. Brown, R.; Civetta, L.; Arienzo, I.; D'Antonio, M.; Moretti, R.; Orsi, G.; Tomlinson, E.L.; Albert, P.G.; Menzies, M. Assembly, evolution and disruption of a magmatic plumbing system before and after a cataclysmic caldera-collapse eruption at Ischia volcano (Italy). Contrib. Mineral. Petrol. 2014, 168, 1035. [CrossRef]

12. Di Napoli, R.; Federico, C.; Aiuppa, A.; D'Antonio, M.; Valenza, M. Quantitative models of hydrothermal fluid-mineral reaction: The Ischia case. Geochim. Cosmochim. Acta 2013, 105, 108-129. [CrossRef] 
13. Heap, M.J.; Kushnir, A.R.L.; Griffiths, L.; Wadsworth, F.B.; Marmoni, G.M.; Fiorucci, M.; Martino, S.; Baud, P.; Gilg, H.A.; Reuschlé, T. Fire resistance of the Mt. Epomeo Green Tuff, a widely-used building stone on Ischia Island (Italy). Volcanica 2018, 1, 33-48. [CrossRef]

14. Poli, S.; Chiesa, S.; Gillot, P.-Y.; Gregnanin, A.; Guichard, F. Chemistry versus time in the volcanic complex of Ischia (Gulf of Naples, Italy): Evidence of successive magmatic cycles. Contrib. Mineral. Petrol. 1987, 95, 322-335. [CrossRef]

15. Brown, R.; Orsi, G.; de Vita, S. New insights into Late Pleistocene explosive volcanic activity and caldera formation on Ischia (southern Italy). Bull. Volcanol. 2008, 70, 583-603. [CrossRef]

16. D'Antonio, M.; Mariconte, R.; Arienzo, I.; Mazzeo, F.C.; Carandente, A.; Perugini, D.; Petrelli, M.; Corselli, C.; Orsi, G.; Principato, M.S.; et al. Combined Sr-Nd isotopic and geochemical fingerprinting as a tool for identifying tephra layers: Application to deep-sea cores from Eastern Mediterranean Sea. Chem. Geol. 2016, 443, 121-136. [CrossRef]

17. Giaccio, B.; Arienzo, I.; Sottili, G.; Castorina, F.; Gaeta, M.; Nomade, S.; Galli, P.; Messina, P. Isotopic (Sr-Nd) and major element fingerprinting of distal tephras: An application to the Middle-Late Pleistocene markers from the Colli Albani volcano, central Italy. Quat. Sci. Rev. 2013, 67, 190-206. [CrossRef]

18. Monaco, L.; Palladino, D.M.; Gaeta, M.; Marra, F.; Sottili, G.; Leicher, N.; Mannella, G.; Nomade, S.; Pereira, A.; Regattieri, E.; et al. Mediterranean tephrostratigraphy and peri-Tyrrhenian explosive activity revaluated in light of the 430-365 kyr record from Fucino Basin (central Italy). Earth-Sci. Rev. 2021, 220, 103706. [CrossRef]

19. D'Antonio, M.; Tonarini, S.; Arienzo, I.; Civetta, L.; Dallai, L.; Moretti, R.; Orsi, G.; Andria, M.; Trecalli, A. Mantle and crustal processes in the magmatism of the Campania region: Inferences from mineralogy, geochemistry, and Sr-Nd-O isotopes of young hybrid volcanics of the Ischia island (South Italy). Contrib. Miner. Petrol. 2013, 165, 1173-1194. [CrossRef]

20. Bourne, A.J.; Lowe, J.J.; Trincardi, F.; Asioli, A.; Blockley, S.P.E.; Wulf, S.; Matthews, I.P.; Piva, A.; Vigliotti, L. Distal tephra record for the last ca 105,000 years from core PRAD 1-2 in the central Adriatic Sea: Implications for marine tephrostratigraphy. Quat. Sci. Rev. 2010, 29, 3079-3094. [CrossRef]

21. Calanchi, N.; Gasparotto, G.; Romagnoli, C. Glass chemistry in volcaniclastic sediments of ODP Leg 107, Site 650, sedimentary sequence: Provenance and chronological implications. J. Volcanol. Geotherm. Res. 1994, 60, 59-85. [CrossRef]

22. Lucchi, F.; Tranne, C.A.; De Astis, G.; Keller, J.; Losito, R.; Morche, W. Stratigraphy and significance of Brown Tuffs on the Aeolian Islands (southern Italy). J. Volcanol. Geotherm. Res. 2008, 177, 49-79. [CrossRef]

23. Keller, J.; Ryan, W.B.F.; Ninkovich, D.; Altherr, R. Explosive volcanic activity in the Mediterranean over the past 200,000 yr as recorded in deep-sea sediments. Geol. Soc. Am. Bull. 1978, 89, 591-604. [CrossRef]

24. Insinga, D.; Tamburrino, S.; Lirer, F.; Vezzoli, L.; Barra, M.; De Lange, G.J.; Tiepolo, M.; Vallefuoco, M.; Mazzola, S.; Sprovieri, M. Tephrochronology of the astronomically-tuned KC01B deep-sea core, Ionian Sea: Insights into the explosive activity of the Central Mediterranean area during the last $200 \mathrm{ka}$. Quat. Sci. Rev. 2014, 85, 63-84. [CrossRef]

25. Orsi, G.; Gallo, G.; Zanchi, A. Simple-shearing block resurgence in caldera depressions. A model from Pantelleria and Ischia. J. Volcanol. Geotherm. Res. 1991, 47, 1-11. [CrossRef]

26. Vezzoli, L. (Ed.) Island of Ischia. In Quaderni de La Ricerca Scientifica; CNR: Rome, Italy, 1988; Volume 114, pp. 1-133.

27. Orsi, G.; de Vita, S.; Di Vito, M.; Isaia, R.; Nave, R.; Heiken, G. Facing volcanic and related hazards in the Neapolitan area. In Earth Sciences in Cities; Heiken, G., Fakundiny, R., Sutter, J., Eds.; The American Geophysical Union: Washington, DC, USA, 2003; pp. 121-170.

28. De Vita, S.; Sansivero, F.; Orsi, G.; Marotta, E. Cyclical slope instability and volcanism related to volcano-tectonism in resurgent calderas: The Ischia island (Italy) case study. Eng. Geol. 2006, 86, 148-165. [CrossRef]

29. Chiodini, G.; Avino, R.; Brombach, T.; Caliro, S.; Cardellini, C.; de Vita, S.; Frondini, F.; Granirei, D.; Marotta, E.; Ventura, G. Fumarolic and diffuse soil degassing west of Mount Epomeo, Ischia, Italy. J. Volcanol. Geotherm. Res. 2004, 133, 291-309. [CrossRef]

30. Piochi, M.; Mormone, A.; Balassone, G. Hydrothermal alteration environments and recent dynamics of the Ischia volcanic island (southern Italy): Insights from repeated field, mineralogical and geochemical surveys before and after the 2017 Casamicciola earthquake. J. Volcanol. Geotherm. Res. 2019, 376, 104-124. [CrossRef]

31. Cusano, P.; Petrosino, S.; De Lauro, E.; Falanga, M. The whisper of the hydrothermal seismic noise at Ischia Island. J. Volcanol. Geotherm. Res. 2020, 389, 1-10. [CrossRef]

32. Poli, S.; Chiesa, S.; Gillot, P.-Y.; Guichard, F.; Vezzoli, L. Time dimension in the geochemical approach and hazard estimates of a volcanic area: The isle of Ischia. J. Volcanol. Geotherm. Res. 1989, 36, 327-335. [CrossRef]

33. Civetta, L.; Gallo, G.; Orsi, G. Sr- and Nd-isotope and trace element constraints on the chemical evolution of Ischia (Italy) in the last 55 ka. J. Volcanol. Geotherm. Res. 1991, 46, 213-230. [CrossRef]

34. Orsi, G.; Piochi, M.; Campajola, L.; D'Onofrio, A.; Gialanella, L.; Terrasi, F. ${ }^{14}$ C geochronological constraints for the volcanic history of the island of Ischia (Italy) over the last 5000 years. J. Volcanol. Geotherm. Res. 1996, 71, 249-257. [CrossRef]

35. Piochi, M.; Civetta, L.; Orsi, G. Mingling in the magmatic system of Ischia (Italy) in the past 5 ka. Miner. Petrol. 1999, 66, 227-258. [CrossRef]

36. Vezzoli, L.; Principe, C.; Malfatti, J.; Arrighi, S.; Tanguy, J.C.; Le Goff, M. Modes and times of caldera resurgence: The <10 ka evolution of Ischia Caldera, Italy, from high-precision archaeomagnetic dating. J. Volcanol. Geotherm. Res. 2009, 186, 305-319. [CrossRef] 
37. de Vita, S.; Sansivero, F.; Orsi, G.; Marotta, E.; Piochi, M. Volcanological and structural evolution of the Ischia resurgent caldera (Italy) over the past $10 \mathrm{ka}$. In Stratigraphy and Geology of Volcanic Areas; Groppelli, G., Viereck-Goette, L., Eds.; Geological Society of America Special Paper: Boulder, CO, USA, 2010; Volume 464, pp. 193-241. [CrossRef]

38. Watts, W.A.; Allen, J.R.M.; Huntley, B. Vegetation history and palaeoclimate of the last glacial period at Lago Grande di Monticchio, Southern Italy. Quat. Sci. Rev. 1996, 15, 133-153. [CrossRef]

39. Crisci, G.M.; de Francesco, A.M.; Mazzuoli, R.; Poli, G.; Stanzione, D. Geochemistry of the recent volcanics of Ischia Island, Italy: Evidences of crystallization and magma mixing. Chem. Geol. 1989, 78, 15-33. [CrossRef]

40. Di Girolamo, P.; Melluso, L.; Morra, V.; Secchi, F.A.G. Evidence of interaction between mafic and differentiated magmas in the youngest phase of activity at Ischia Island (Italy). Per. Miner. 1995, 64, 393-411.

41. Melluso, L.; Morra, V.; Guarino, V.; de' Gennaro, R.; Franciosi, L.; Grifa, C. The crystallization of shoshonitic to peralkaline trachyphonolitic magmas in a $\mathrm{H}_{2} \mathrm{O}-\mathrm{Cl}-\mathrm{F}-$ rich environment at Ischia (Italy), with implications for the feeder system of the Campania Plain volcanoes. Lithos 2014, 210, 242-259. [CrossRef]

42. Iovine, R.S.; Mazzeo, F.C.; Arienzo, I.; D’Antonio, M.; Wörner, G.; Civetta, L.; Pastore, Z.; Orsi, G. Source and magmatic evolution inferred from geochemical and Sr-O-isotope data on hybrid lavas of Arso, the last eruption at Ischia island (Italy; 1302 AD). J. Volcanol. Geotherm. Res. 2017, 331, 1-15. [CrossRef]

43. Pelullo, C.; Cirillo, G.; Iovine, R.S.; Arienzo, I.; Aulinas, M.; Pappalardo, L.; Petrosino, P.; Fernandez-Turiel, J.L.; D'Antonio, $\mathrm{M}$. Geochemical and $\mathrm{Sr}-\mathrm{Nd}$ isotopic features of the Zaro volcanic complex: Insights on the magmatic processes triggering a small-scale prehistoric eruption at Ischia island (south Italy). Int. J. Earth Sci. 2020, 109, 2829-2849. [CrossRef]

44. Acocella, V.; Funiciello, R. The interaction between regional and local tectonics during resurgent doming: The case of the island of Ischia, Italy. J. Volcanol. Geotherm. Res. 1999, 88, 109-123. [CrossRef]

45. Paoletti, V.; D'Antonio, M.; Rapolla, A. The structural setting of the Ischia Island (Phlegrean Volcanic District, Southern Italy): Inferences from geophysics and geochemistry. J. Volcanol. Geotherm. Res. 2013, 249, 155-173. [CrossRef]

46. Micro-Analysis Consultants Ltd. Available online: http:/ / www.macstandards.co.uk (accessed on 30 June 2021).

47. Jarosewich, E.; Nelen, J.A.; Norberg, J.A. Reference samples for electron microprobe analysis. Geostand. Geoanal. Res. 1980, 4, 43-47. [CrossRef]

48. Whitney, D.L.; Evans, B.W. Abbreviations for names of rock-forming minerals. Am. Mineral. 2010, 95, 185-187. [CrossRef]

49. Deer, W.A.; Howie, R.; Zussman, J. An Introduction to the Rock-Forming Minerals, 2nd ed.; Pearson Education Limited: London, UK, 1992; pp. 1-712.

50. Yavuz, F. PYROX: A computer program for the IMA pyroxene classification and calculation scheme. Comput. Geosci. 2001, 27, 97-107. [CrossRef]

51. Rock, N.M.S. The International Mineralogical Association (IMA/CNMMN) pyroxene nomenclature scheme: Computerization and its consequences. Mineral. Petrol. 1990, 43, 99-119. [CrossRef]

52. Yavuz, F. Evaluating micas in petrologic and metallogenic aspect: I-definitions and structure of the computer program MICA ${ }^{+}$. Comput. Geosci. 2003, 29, 1203-1213. [CrossRef]

53. Stormer, J.C., Jr. The effects of recalculation on estimates of temperature and oxygen fugacity from analyses of multicomponent iron-titanium oxides. Am. Mineral. 1983, 68, 586-594.

54. Lepage, L.D. ILMAT: An Excel ${ }^{\circledR}$ worksheet for ilmenite-magnetite geothermometry and geobarometry. Comput. Geosci. 2003, 29, 673-678. [CrossRef]

55. Yavuz, F. WinAmphcal: A Windows program for the IMA-04 amphibole classification. Geochem. Geophys. Geosyst. 2007, 8, 1-12. [CrossRef]

56. Altaner, S.; Demosthenous, C.; Pozzuoli, A.; Rolandi, G. Alteration history of Mount Epomeo Green Tuff and a related polymictic breccia, Ischia Island, Italy: Evidence for debris avalanche. Bull. Volcanol. 2013, 75, 718. [CrossRef]

57. Le Maitre, R.W. (Ed.) Igneous Rocks. A Classification and Glossary of Terms. Recommendations of the International Union of Geological Sciences Subcommission on the Systematics of Igneous Rocks, 2nd ed.; Cambridge University Press: Cambridge UK, 2005; pp. 1-236.

58. Alekseyev, V.A.; Medvedeva, L.S.; Prisyagina, N.I.; Meshalkin, S.S.; Balabin, A.I. Change in the dissolution rates of alkali feldspars as a result of secondary mineral precipitation and approach to equilibrium. Geochim. Cosmochim. Acta 1997, 61, 1125-1142. [CrossRef]

59. Larsson, D.; Grönvold, K.; Oskarsson, N.; Gunnlaugsson, E. Hydrothermal alteration of plagioclase and growth of secondary feldspar in the Hengill Volcanic Centre, SW Iceland. J. Volcanol. Geotherm. Res. 2002, 114, 275-290. [CrossRef]

60. D'Antonio, M.; Kristensen, M.B. Hydrothermal alteration of oceanic crust in the West Philippine Sea Basin (Ocean Drilling Program Leg 195, Site 1201): Inferences from a mineral chemistry investigation. Mineral. Petrol. 2005, 83, 87-112. [CrossRef]

61. Plümper, O.; Putnis, A. The complex hydrothermal history of granitic rocks: Multiple feldspar replacement reactions under subsolidus conditions. J. Petrol. 2009, 50, 967-987. [CrossRef]

62. Kontonikas-Charos, A.; Ciobanu, C.L.; Cook, N.J. Albitization and redistribution of REE and Y in IOCG systems: Insights from Moonta-Wallaroo, Yorke Peninsula, South Australia. Lithos 2014, 208, 178-201. [CrossRef]

63. Rittmann, A. Geologie der Insel Ischia. Zeitschr. Vulkanol. Ergbd. 1930, 6, 1-265.

64. Allen, J.R.M.; Brandt, U.; Brauer, A.; Hubberten, H.W.; Huntley, B.; Keller, J.; Kraml, M.; Mackensen, A.; Mingram, J.; Negendank, J.F.W.; et al. Rapid environmental changes in southern Europe during the last glacial period. Nature 1999, 400, 740-743. [CrossRef] 
65. Kraml, M. Laser- ${ }^{40} \mathrm{Ar} /{ }^{39} \mathrm{Ar}$-Datierungen an distalen marinen Tephren des jung-quartären mediterranen Vulkanismus (Ionisches Meer, METEOR-Fahrt 25/4). Ph.D. Thesis, University of Freiburg, Freiburg, Germany, 1997; 216p.

66. Narcisi, B.; Vezzoli, L. Quaternary stratigraphy of distal tephra layers in the Mediterranean-an overview. Glob. Planet. Chang. 1999, 21, 31-50. [CrossRef]

67. Rosi, M.; Sbrana, A.; Vezzoli, L. Correlazioni tefrostratigrafiche di alcuni livelli di Ischia, Procida e Campi Flegrei. Mem. Soc. Geol. It. 1988, 41, 1015-1027. (In Italian)

68. Tamburrino, S.; Insinga, D.D.; Pelosi, N.; Kissel, C.; Laj, C.; Capotondi, L.; Sprovieri, M. Tephrochronology of a 70 ka-long marine record in the Marsili Basin (southern Tyrrhenian Sea). J. Volcanol. Geotherm. Res. 2016, 327, 23-39. [CrossRef] 